\title{
GLYCOGEN IN THE NERVOUS SYSTEM OF VERTEBRATES
}

\author{
SIMON H. GAGE \\ Cornell University, Ithaca, N. Y. \\ TEN Figures (ONe plate) \\ HISTORICAL SUMMARY
}

The brilliant series of investigations by Claude Bernard on sugar in the blood which culminated in his discovery and isolation of glycogen in 1857 , may justly be characterized as epochmaking for the understanding of animal physiology, and a proper correlation of the physiology of animals and plants, and their fundamental similarity.

In this series of investigations, Bernard was disturbed and puzzled by not finding at any period of the life of animals glycogen in the nervous system. He missed it also in other organs and tissues, but all the gaps were filled up by one investigator or another until in 1904 the glycogenic function had been demonstrated in some stage of development for all organs and tissues except the nervous system.

This is what Bernard himself says ('59) and practically repeats in all of his published papers and books upon Glycogen:

A aucune époque de l'évolution organique, je n'ai pu constanter la matière glycogène dans les tissue nerveux. J'ai traité, soit par la coction, soit par divers autres moyens précedemment indiqués, le cerveau, la moelle épinière . . . . chez des foetus d'homme, de veau, de mouton, de lapin, et à aucune age je n'ai pu y constater la moindre trace de matière glycogène.

Barfurth ('85, p. 299) referring to what Bernard says concerning glycogen in the nervous system of vertebrate embryos, says: "Ich kan diese Angeben lediglich bestätigen." 
In Pflüger's book on glycogen (2nd edition, '05, pp. 159-160) is the statement with reference to the nervous system of the adult; that Pavy (1881 had reported the presence of glycogen in a normal adult brain analyzed by him, and that Cramer ('80) had found traces in the brain of a person dead of diabetes. On the other hand Barfurth ('85, p. 297) and others, reporting the analyses for the normal adult brains of rabbits and dogs, asserted that no glycogen was found by them.

Pflüger says further on with reference to glycogen in the nervous system in embryos:

Auch im Embryonalzustand ist bisher kein Glykogen in der sich bildenden Nervensubstanz aufgefunden worden, was bereits Claude Bernard untersucht. In neuester Zeit haben G. Fichera ('04) sowohl als E. Gierke ('05) das Nervensystem auf Glycogen untersucht und nur negative Ergebnisse gemeldet.

In $1904 \mathrm{I}$ was fortunate enough to discover the presence of glycogen in the nerve cells of the central nervous system of Amphioxus, and began then a systematic investigation of the nervous system of vertebrates, believing that in some period of development glycogen would be found in the nervous system of each form in the ascending series up to and including man. The following paper is a summarized statement of the results of the work up to the present. For the more extended study, forms were selected in which abundant material, in all stages of embryonic as well as in adult life, could be easily obtained. These forms are: Petromyzon to represent the available form nearest to Amphioxus; Amblystoma punctatum, among the amphibians; the chick (Gallus domesticus) among the birds; and the pig (Sus scrofa) among the mammals. Other forms, including human material, were studied whenever opportunity offered.

In a word, it may be stated that the hopes held out by the discovery of glycogen in Amphioxus were abundantly fulfilled, for glycogen was found in large amounts in some stage of development in the nervous system of every form studied.

In carrying on the investigation microchemical methods were used, and not the usual analyses of entire animals or organs. On showing microscopical specimens containing glycogen to 
chemists it was pointed out by them that where large amounts of glycogen might be present in some elements of the organ or animal, the amount of glycogen relative to the entire bulk might be so small that it would be wholly missed by the usual chemical analyses. It is also now recognized that chemical analyses by the aid of the microscope have as great validity as those made in the usual way, where relatively large amounts of substance and reagents must be used (Chamot, '15). Furthermore, the microscopical method is the only one by which the exact anatomical location of the glycogen can be determined. For the precise steps employed in fixing, imbedding, sectioning, and staining and mounting tissues for glycogen, see the note at the end of this paper. It may be stated here that to make sure that the mahogany red substance shown in the nerve cells is glycogen, the test was made in every case with saliva, which transforms glycogen to sugar and therefore renders it no longer stainable with iodin; it is believed therefore that the results here given, and which were obtained over and over on many different specimens, can be relied upon.

GLYCOGEN IN THE NERVOUS SYSTEM OF AMPHIOXUS AND ASYMMETRON FROM BERMUDA AND AMPHIOXUS FROM NAPLES

In 1904 while a member of the group of workers at the Bermuda Biological Station, under the direction of Dr. E. L. Mark, advantage was taken of the abundant Amphioxus material there available to investigate the tissues for glycogen. It was found rather generally distributed but not in striking amounts except in the most unexpected situation, viz., in the large nerve cells of the central nervous system. This was so opposed to the findings of all previous investigators of glycogen in the nervous system that it was. only after repeated verifications on specimens of various sizes that it was accepted. While any nerve cell apparently might contain glycogen, this substance was most strikingly shown in the large nerve cells associated with pigment. Whether or not there is any connection, it is a rather striking fact that glycogen in large amount is found in the retinal nerve cells of 
adult Petromyzon, in some teleosts Ameiurus, and may be found in the retinae of higher forms when sufficiently investigated.

Fortunately Bermuda has also in its waters the little Amphioxus discovered by Andrews in the Bahamas (Asymmetron lucayanum). Asymmetron showed also glycogen in the nerve cells, agreeing in every particular with Amphioxus. Through the courtesy of The Wistar Institute, I was enabled to examine Amphioxus from Naples also, and found glycogen in even greater abundance if possible in its nerve cells. Probably glycogen is present in the nerve cells of Amphioxus wherever found.

GLYCOGEN IN THE CENTRAL NERVOUS SYSTEM AND RETINA OF THE LAKE LAMPHREY (PETROMYZON MARINUS UNICOLOR),

AND THE BROOK LAMPREY (LAMPETRA WILDERI) OF THE CAYUGA LAKE BASIN

After finding glycogen in the nerve cells of Amphioxus it seemed probable-at least not improbable--that it might be found in the nervous system of Ammocoetes (larval Petromyzon and Lampetra), whose life habits are so similar to Amphioxus, although living only in fresh water. On returning to Ithaca from Bermuda, larval lampreys of all sizes were obtained in nature and put directly into 95 per cent alcohol and some also in absolute alcohol, exactly as had been done for Amphioxus. On sectioning and staining this material, glycogen was found as hoped, and it was in brain cells as well as in those of the myel (medulla spinalis). Not all nerve cells contain glycogen, but many of them. In the larval Petromyzon (Ammocoetes) there was another striking fact brought out in the sections: The tissue surrounding the central nervous system has the general appearance of fat; with the glycogen stain almost every cell showed abundant glycogen. in a part of the cell. On using Sudan III, and osmic acid, as well as the glycogen stain, it appeared that the cells in the loose tissue enclosing the central nervous system were most of them filled in part with fat and in part with glycogen. The cells in the dorsal region of the abdomen around the mesonephros and gonads were also in many cases partly surrounded by similar cells filled with fat and with glycogen. 
In sections through the entire head of ammocoets the undeveloped eyes were sectioned and much glycogen found in the cones, no rods being present in the petromyzon eye at any stage of development.

The presence of glycogen in the retinal cones of the frog was called attention to long ago by Ehrlich ('83), and recently there has appeared a paper by Brammertz ('15) in which glycogen is asserted to be present in the retinal rods and cones of the frog, the pigeon, and the rabbit.

In the adult Petromyzon and Lampetra, the eye always contains glycogen, but not in the cones. The glycogen in the functioning eye is in the retinal nerve cells (fig. 4); and very importantly as it appears to me, even in the stages of advanced starvation after the spawning. Vision seems to be of the highest importance for the lamprey in the shallow streams during its spawning period; and that the vision is good every one will be willing to concede who attempts to catch them. In addition to the glyccgen in the retina proper, the arachnoid layer of the eyeball near the optic nerve is filled with cells containing a large amount of glycogen. That is much more marked in the lampreys during the vegetative, or growing and maturing period than late in the spawning season.

In passing, attention might be called to a very striking peculiarity of the petromyzon retina. The optic nerve, instead of passing through all the layers of the retina and finally spreading out on the inside next the vitreous, only extends about half way through the thickness and then spreads out. As the optic nerve leaves the retina on its way to the brain, the fibers decussate. The lamprey eye certainly deserves more attention than has been accorded to it.

In the course of development of Petromyzon the ova show no glycogen until the eggs are ripened and ready to be shed and, of course, immediately afterward; then the glycogen is abundant and scattered between the yolk granules (fig. 5). It is in very fine granules and especially abundant near the periphery of the egg. As the ovum segments, the glycogen is most marked in the mitotic areas of the cells, and as segmentation proceeds it 
becomes most condensed at the animal pole and finally in the medullary region which gives rise to the central nervous system. In embryos 5 to $10 \mathrm{~mm}$. long it is marked in the central nervous system. It is at this time present between the granules of food yolk, also in the myotomes, notochord, connective tissue, nephric system, cardiac muscle, liver diverticulum, and epidermis.

In embryos of 10 to $17 \mathrm{~mm}$., in which the food yolk has mostly disappeared, glycogen is present as in the younger embryos, and has appeared in the brain plexus, retina, and auditory epithelium. It is also present in the enteric epithelium.

With larger, well fed specimens, besides the nervous system, the tissues containing glycogen are those of the heart, both auricle and ventricle, branchial epithelium, thyroid duct, branchial cartilages, and their striated muscles, and the muscle of the velum, which has only a striated periphery. The glycogen is in the granular non-striated central part of the velar muscle. In the digestive tract it is found in the gall duct and in the liver; also in the intestinal epithelium, especially the terminal third. In the urinary system it is found in the nephrostomes, and in both pro- and mesonephros, also in the Wolffian duct. It is present in skeletal muscles, the notochord, the primitive skull cartilages, the ear capsule, the fat cells, around the central nervous system and that on the ventral side of the notochord, some of the epidermis, expecially that of the branchial region and the oral hood, the epithelium of the nose and the ear.

\section{AMBLYSTOMA PUNCTATUM}

In this salamander, as with most of the Amphibia, the independent life of the young commences very early, and on the alertness in escaping enemies and in obtaining food depends its existence. Going with this early activity is the presence of glycogen in large amount in the unsegmented egg, and in all stages of segmentation. During segmentation glycogen is more abundant in the animal than in the vegetative pole of the ovum. While glycogen is more abundant in the animal pole, as segmen- 
tation proceeds and the germ layers are formed it is present in all germ layers but is especially marked in the neural plate.

Glycogen appears in the first proton or anlage of the eye, ear, and nose; in the brain and the myel (medulla spinalis) and in all the organs and tissues of the embryo; that is, in Amblystoma glycogen is universal in its distribution throughout the body in the early embryonic condition, but the liver early takes on the most prominent glycogenic function. It persists for a long time, perhaps throughout life in the cardiac muscle and in the retina (rods and cones).

\section{GALLUS DOMESTICUS}

In the chick glycogen appears first in the cardiac muscle, thirty-sixth to the forty-eighth hour of incubation. In strong contrast with Petromyzon and Amblystoma, the appearance of the glycogen in the nervous system is late. In the sixth to the tenth day, it is very abundant in the medulla oblongata and in the sacral and lumbar myel (medulla spinalis).

In the tenth day it appears in cartilage and in the muscles of the trunk and limbs, but it is not so abundant in the somatic muscles of the chick as in those of Petromyzon and mammalian embryos. It is also present, to a limited extent, in the epidermis and the enteric epithelium.

It has already been pointed out by many previous workers that glycogen is not so abundant in the organs and tissues of the chick as in the embryos of many other forms, including mammals. It seems to me that this is true if one deals with the glycogenesis in all of the organs at any one period. With the large amount of stored food in the hen's egg, the chick has the advantage of developing at leisure, so to speak, and whenever the time arrives to bring to definitive form or activity any tissue, the glycogenic builder and energy producer is on hand, but as these perfecting processes do not occur in all the organs and tissues of the chick practically at the same time as with Amblystoma, one finds abundant glycogen at any one period only in a limited region of the body. 


\section{GLYCOGEN IN THE NERVOUS SYSTEM OF MAMMALS}

Sus scrofa. The pig was selected for determining the presence of glycogen in the nervous system of mammals because of the abundance of material obtainable at all periods of development. Other mammals were examined as opportunity offered, and it was found that whatever occurred in the pig appeared also in other mammals if taken at the favorable developmental state.

Up to the present, glycogen has been found by me in the cells of the dorsal root ganglia of pigs up to a length $15 \mathrm{~mm}$., those of 10 to $12 \mathrm{~mm}$. in length had perhaps the greatest number of nerve cells with the glycogen. At this time the outgrowing nerves seem to be wholly free from glycogen, but commencing with embryos of $30 \mathrm{~mm}$. and as large as $70 \mathrm{~mm}$. and perhaps older ones, the nerves within and beyond the ganglion are so filled with glycogen that they appear a deep brown.

In addition to the nervous element proper, the endymal cells of the relatively free choroid plexus are filled with it in the older embryos, i.e., those of 40 to $70 \mathrm{~mm}$. and perhaps older ones. In addition to the cells on the free plexus, those extending for a considerable distance upon the ventricular wall are well supplied with glycogen.

In the fourth ventricle the endymal cells contain glycogen at a somewhat later stage, viz., in embryos of 50 to $75 \mathrm{~mm}$. in length.

Abundant glycogen was also found in the olfactory as well as the respiratory epithelium of the nose; and its presence is very marked in the epithelium of the cochlear canal opposite the organ of Corti. The eye has not yet been sufficiently studied, but the appearance of glycogen at some period is predicted. Glycogen was found in every organ and tissue in the body of pig embryos at some period of development. Naturally the heart contained much of it. For example, in the smaller pigs studied, i.e., those of 8 to $16 \mathrm{~mm}$., the cardiac glycogen was so abundant that it made the heart sections almost opaque. In embryos of $70 \mathrm{~mm}$. the amount was relatively less. The liver contained no 
glycogen in any of the embryo pigs studied, thus agreeing with the statements of Bernard that glycogen is relatively late in appearing in the liver.

In the alimentary canal the glycogen passes as a kind of wave along the tube, commencing at the mouth and passing in order to the esophagus, the stomach, and, as the villi commence to appear, extending along down the small to the large intestine.

The investigation of human embryos for glycogen is carried on with more uncertainty than is that for other forms owing to the difficulty of obtaining material in the different stages which can be fixed in the alcohol before the glycogen becomes dissolved. However, owing to the courtesy of Dr. Mall, and several of my old students, some fairly normal human embryos fixed in alcohol before all of the glycogen was dissolved, have been studied, and I have found the glycogen distributed among the organs and tissues as described for mammals generally.

In the nervous system, the only unmistakable situation in which it has been found up to the present is in the choroid plexus of a $19 \mathrm{~cm}$. human fetus and in the choroid plexus and the cells of the raphé of the medulla oblongata of a $35 \mathrm{~mm}$. human embryo preserved in strong alcohol. The endymal cells showed the same abundance of glycogen that has been found in the embryo of the cat and pig. A figure of this human plexus with the glycogenated endymal cells is given in the accompanying plate (fig. 10). It is confidently expected that when the proper material can be obtained glycogen will be found in the human nervous system and organs of sense, as with other mammals.

\section{CONCLUSIONS}

From the data given above it is believed that the following conclusions may be fairly drawn:

1. The production and use of glycogen is one of the properties of nervous as of all other forms of protoplasm.

2. Glycogen is an essential accompanier of nervous as of all other tissues in their histogenesis, especially in the transition to their definitive and functional stage. 
3. Glycogen is, then, a builder as well as an energy producer for nervous as for all other forms of tissue.

4. Its appearance in developing tissue in all forms of vertebrates depends in part, at least, upon the relative time in which the tissues must function. For example in Amblystoma that must have full functional activity very early in its life, the perfecting glycogen appears correspondingly early, while with the chick it is late in appearing.

5. After reaching their definitive form the elements of the nervous system in the lowest vertebrates, Amphioxus and larval lampreys (Ammocoetes), continue their glycogenic function in the central nervous system. In the adult lampreys (Petromyzon and Lampetra), this function persists throughout life in the nerve cells of the retina. With the higher vertebrates, glycogen in demonstrable amount is not found in the nervous system after the embryonic period, the liver and muscles then assuming the main glycogenic function.

That is, specialization of this function keeps pace with differentiation of structure consequent upon advance in the zoölogical scale.

\section{METHOD OF DEMONSTRATING GLYCOGEN}

The fundamental thing is that no liquid is to be used in any of the steps that will dissolve the glycogen. The most certain medium for fixing is alcohol. Absolute alcohol is mostly recommended; but, as glycogen is wholly insoluble in alcohol of 67 per cent and, of course, in all stronger grades, one has considerable range.

As alcohol diffuses through the tissues slowly, only small animals and small embryos should be fixed entire. For the organs and tissues of larger forms small pieces or widely opened and dissected organs in which the alcohol comes quickly in contact with all the parts containing glycogen should be used. Plenty of alcohol should be used-fifty times the bulk of the tissue--and it is well to change it two or three times. In general it is safer to use alcohol of 95 per cent, then it is not liable to be diluted by the lymph sufficiently to make the glycogen soluble.

As alcohol distorts the tissues, it is well to carry along parallel specimens prepared by the usual fixers. Mercuric chlorid, or mercuric chlorid and dichromate mixtures are good. Picric alcohol is also good and it has the advantage of fixing the glycogen as well as the other tissue elements (it is composed of 67 per cent alcohol, 500 cc.; picric acid, 1 
gram). The tissue is fixed in this twelve to twenty-four hours and then transferred to 67 per cent alcohol the same time; and then for a day or more in 82 per cent alcohol before the final imbedding. Plenty of fixer and alcohol should be used.

Other fixers have been recommended for glycogen, and many different ones preserve a part of the glycogen, but as the purpose of any investigation on glycogen is to find all the elements in which it is present either in large or in small amounts, a fixer should be used which experience has shown to be the most precise and certain, and that fixer is alcohol.

For large embryos, small animals, limbs, etc. containing bone it was found entirely practicable to decalcify the bone without in any way disturbing the glycogen. The embryo, animal or part is fixed with alcohol as usual for glycogen, then it is placed in the nitric acid decalcifier composed of 67 per cent alcohol to which has been added 3 per cent nitric acid. After the decalcification is complete, the embryo remains a day or two in 67 per cent alcohol, changed two or three times. It is then transferred to 82 per cent alcohol for a day or more before dehydrating and imbedding.

Imbedding and sectioning. Either the collodion or the paraffin method can be used. The paraffin method or the combined collodion and paraffin method has proved most satisfactory in my work. Some of the sections should be moderately thick, 10 to $15 \mu$. Sections less than $5 \mu$ are not serviceable for glycogen investigations.

Staining glycogen. The only fully reliable and satisfactory stain for glycogen is iodin. As some glycogen is very soluble, a glycogen stain containing alcohol was found most generally useful $(95$ per cent alcohol, $150 \mathrm{cc}$; water, $150 \mathrm{cc}$; iodin crystals, 1.5 grams or $15 \mathrm{ce}$. of a 10 per cent alcoholic solution of iodin; iodid of potassium, 3 grams; sodium chlorid, 1.5 grams). For the aqueous stain, water is used instead of the alcohol mixture.

For staining, spread the paraffin sections with the iodin stain instead of water. The glycogen in the sections will stain a mahogany red and the stain will remain in the spread sections for years (10 to 15). If care is taken not to melt the paraffin when spreading the sections, they can be restained at any time by immersing the slide in the stain or placing some of the stain on the sections.

Permanent preparations. The permanence of the iodin stain in the spread paraffin sections gave the clue. For low powers the sections in paraffin show very well without further preparation, but for high powers the crystals of paraffin interfere. Various paraffin media were tried, and finally ordinary yellow vaseline was settled upon as best. For mounting, the sections are restained by immersing the slide in the iodin stain for two to three minutes or longer; they are then dried half an hour or more in the air or in a drying oven, then immersed in xylene to dissolve off the paraffin. Some melted yollow vaseline is then put on the sections and a cover-glass added exactly 
as in balsam mounting. As the vaseline does not hold the cover very firmly, it is best to seal the cover with shellac.

Specimens so stained may be restained at any time by reversing the process and then remounting. The stain remains for two to ten years.

A second method was to mount in Canada balsam without a coverglass, as with the Golgi preparations. For this dried balsam is powdered and to 25 grams of dry balsam, 50 ce. of xylene is added. The sections are deparaffined, and the balsam put over them and allowed to dry in the air. More than one coat of balsam may be needed.

The glycogen stain is not so persistent in the balsam, but for high power work the finest details are more satisfactory. If a homogeneous immersion objective is to be used the original immersion liquid, viz., Canada balsam of moderate thickness is better than cedar oil. It need not be removed. The other stains recommended for glycogen are not so precise as iodin, and are liable, if not checked by iodin, to lead the investigator astray.

The most exact test for glycogen is saliva. If a section is deparaffined, washed off with alcohol and water, and then saliva put upon it for half an hour, if the substance is glycogen it will be changed to sugar by the enzyme of the saliva. If now the section is restained with iodin no mahogany red glycogen will appear. This test was applied to all the work given in the accompanying paper to make sure that the reddish brown substance in the cells was glyeogen and not something else.

\section{BIBLIOGRAPHY}

The literature of glycogen is very extensive, and may be found in the Index Catalogue of the Library of the Surgeon General's Office, Ser. I, II, and in special papers such as Fichera's with its 311 references and in Pflüger's book on Glycogen. Only the works bearing directly upon the subject of this discussion are here given.

Barfurth, D. 1885 Vergleichend-histochemische Untersuchungen über das Glycogen. Arch. f. mikr. Anat., Bd. 25, pp. 261-404. Nervous system of vertebrates, pp. 297, 299. Invertebrates, p. 298. While denying glycogen to vertebrate nervous tissue at any period, p. 299, he reported its presence in small amounts in the nervous system of snails.

Bernard, Clande 1859 De la matière glycogène considerée comme condition de développement de certain tissus chez le foetus avant l'apparition de la fonction glycogénique du foie. Jour. de la Physiol. t. 2, Pp. 326-337.

1878-1879 Leçons sur les phénomènes de la vie communs aux animaux et aux végétaux. Two volumes.

Bernard wrote many papers upon sugar in the blood and upon glycogen, which he discovered and isolated in 1857. The paper cited above and the volumes on the phenomena of life give his views very 
completely. It may be said in passing that physiologists have not gone far beyond Bernard. It is however, more widely distributed than he thought, and its locations have been more completely mapped out since his day.

Brammertz, WM. 1915 Ueber das normale Vorkommen von Glykogen in der Retina. Arch. f. mikr. Anat., Bd. 86, pp. 1-7. He reports the presence of glycogen in the rods and cones of frog, pigeon, rabbit and between them in the pike, and in the eye of the house fly.

Creighton, Charles 1896-1899 Microscopic researches on the formative property of glycogen. Part I with five colored plates, 152 pages. Part II ('99), Glycogen of snails and slugs. Nine plates, 127 pages. In Part $\mathrm{I}$ he figures and discusses glycogen in the choroid plexus of the cat embryo, pl. i, figure 3 ; and a combination of fat and glycogen in the developing mammary gland, pl. iv, figure 20. All students of glycogen would do well to consult this work.

Chamot, E. M. 1915 Elementary chemical microscopy.

Duggar, B. M. 1911 Plant physiology. This work gives a good account of starch and its transformations in plants.

Fichera, G. 1904 Ueber die Verbreitung des Glycogens in Verschiedenen Arten. Ziegler's Beitröge zur path. Anat., Bd. 36, pp. 273-339. Fichera gives references to 311 papers.

GAGE, S. H. 1905-1906 Glycogen in the nervous system. Reports and demonstrations at the Association of American Anatomists. Am. Jour. Anat., 1905, pp. xii-xiii; 1906 , pp. xiii-xv.

Lusk, Graham 1906 The elements of the science of nutrition. Discusses carbohydrates, including glycogen, in nutrition.

Mendel, L. B. and Leavenworth, C. S. 1907, The American Journal of Physiology, vol. 20, pp. 117-126. Chemical studies on growth; III, the occurrence of glycogen in the pig. They used the brain substance in rather large amounts and got only negative results. Their final conclusion is that embryos do not have a large amount of glycogen in their tissues. The author showed Dr. Mendel the microscopic sections of embryo pigs and he could not help thinking that a great deal of glycogen was present. In case of the brain it is entirely possible that the amount of glycogen in the choroid plexus might not be sufficient to give results in ordinary analyses, although they are most striking and convincing in microseopic preparations.

PrLügrR, E. F. W. 1905 Das Glykogen und seine Beziehungen zur Zuckerkrankheit. Zweite Auflage. Very many references.

Smith, Lucy Wright 1912 Glycogen in Insects, especially in the nervous system and eyes. Science, vol. 35, March 1. Much glycogen is found in both compound and simple eyes and in the nerve cells of the ganglia from all parts of the body, but not in the nerve fibers. 


\section{PLATE 1}

\section{EXPLANATION OF FIGURES}

1 Glycogenated nerve cells of Amphioxus.

2 Nerve cells of Ammocoetes from the brain opposite the eye and ear.

3 Nerve cells in the myel (medulla spinalis) of Ammocoetes with glycogen; also glycogen and fat in the same cells.

4 Retina of an adult Petromyzon showing glyeogen in the retinal nerve cells, and the decussation of the optic fibers.

(a) Edge view of glycogenated retinal nerve cells.

(b) Face view of retinal nerve cells.

5 Ova of Petromyzon and Amblystoma (bc) showing the great amount of glycogen in the cells of the animal pole. In the developing nervous system there is much glycogen.

6 Lumbar enlargement of a ten day chick's medulla spinalis showing a prismatic mass of glycogenated cells in the raphé. A similar glycogenated area is present in the medulla oblongata.

7 Spinal ganglion of a $12 \mathrm{~mm}$. pig embryo with glycogenated cells. (a) Some of the cells greatly enlarged.

8 Glycogenated nerve trunks of the brachial plexus of a $30 \mathrm{~mm}$. pig embryo.

9 Glycogenated endymal cells of the brain plexuses in a cat embryo. (a) Endymal cells greatly enlarged.

10 Choroid plexus of a $19 \mathrm{~cm}$. human embryo. (ab) Section through the cerebrum and medulla of a $35 \mathrm{~mm}$. human embryo to show the glycogenated choroid plexus and the cells of the raphé in the medulla. 

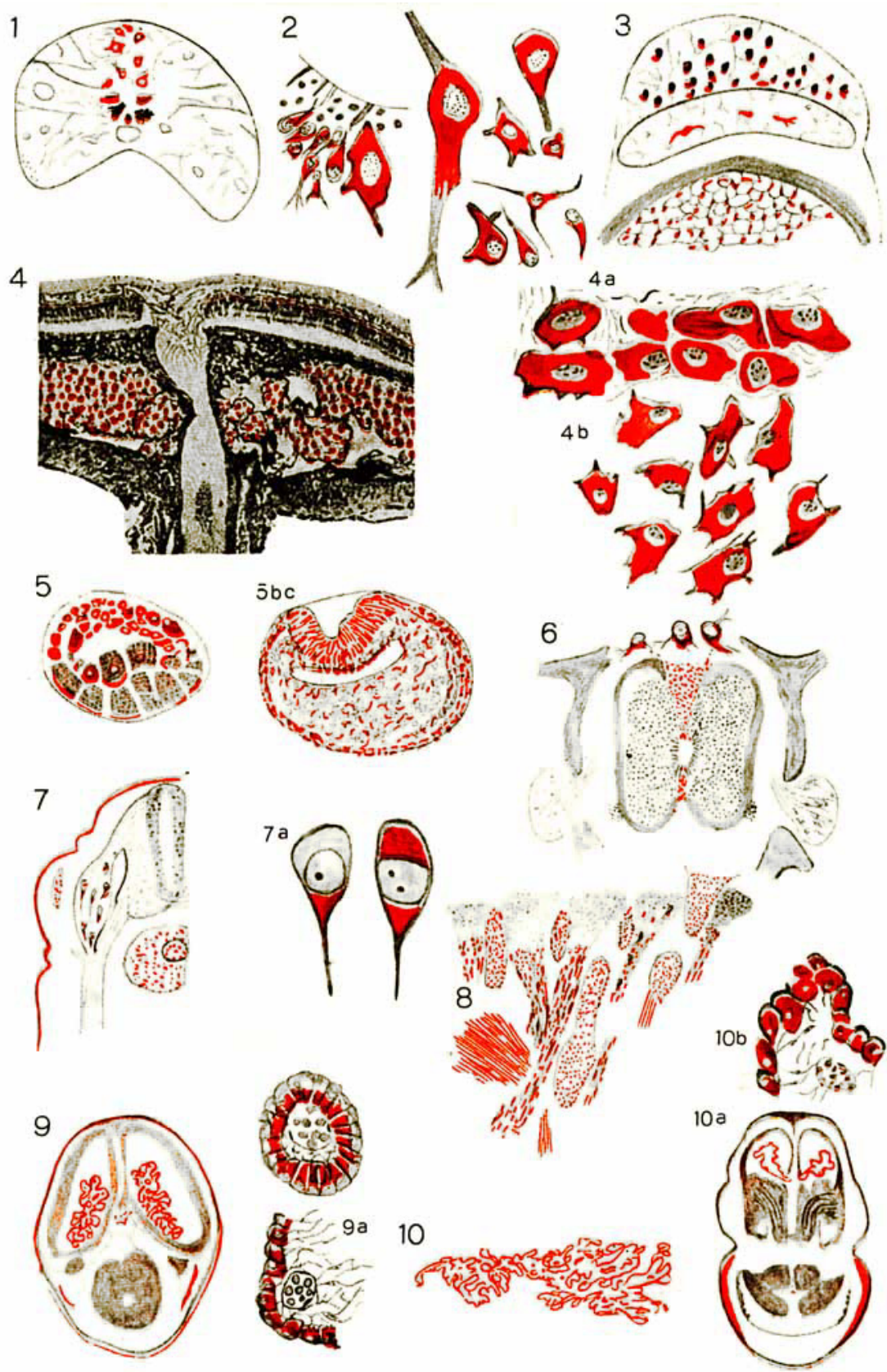